\title{
Q marks the spot as ancient sculptures yield their origins
}

Archaeologists have pinpointed the location of a long-sought Maya city in Guatemala. The discovery could bolster scientists' battle against local ranchers, who have been moving into the surrounding national park claiming the land as their own.

For several decades, Maya experts have puzzled over some 30 enigmatic sculptures - most of them carved stone blocks - that came to light around the world but seemed to have originally come from the same place. No one knew where the site was. Archaeologists dubbed it 'Site Q', the Q standing for the Spanish 'quê, meaning 'what?' or 'which?'.

Last week, a team of archaeologists announced that they had found Site Q. It was, they said, the ancient city known as La Corona in the Petén region of northern Guatemala.

La Corona came to the attention of archaeologists in 1997, when Harvard University researchers Ian Graham and David Stuart visited and documented the ruins. They found sculptures that resembled the Site Q monuments. "I've always been convinced that $\mathrm{La}$ Corona is the place," says Stuart, now at the University of Texas at Austin.

The latest finding may convince everyone else. In April, a small team briefly visited La Corona under the direction of Marcello Canuto, an archaeologist at Yale University in New Haven, Connecticut. Canuto found the Site $Q$ connection by chance, while trying to escape the jungle's relentless mosquitoes.
He came across a trench dug by looters years before, and there discovered an elaborately carved stone block still in its original setting. The carvings on the stone matched those of the Site Q sculptures and thus prove that $\mathrm{La}$ Corona is Site $\mathrm{Q}$ says Canuto.

Hieroglyphs on the panel date it to the year $\mathrm{AD} 677$ and describe key rulers, religious dates and other events. The panel also describes how La Corona was a key ally of the city of Calakmul; the Maya world at the time was ruled by two cities, Calakmul and Tikal, which were fierce enemies.

Unlike the well-known monuments at Tikal, the recordings of Calak-
mul's history have mostly eroded away, says Canuto. "If La Corona was a faithful ally, this discovery will add a lot of information about Calakmul's history," he adds.

Meanwhile, David Freidel, another team member and an anthropologist at the Southern Methodist University in Dallas, Texas, is working with Guatemalan researchers and conservation agencies on another aspect of the find. They are trying to get the area designated as an archaeological park that should be protected. La Corona lies in a national park that is meant to be kept pristine. But ranchers threaten the sites more each year, says Freidel. During some seasons, the fires they set to dear land can come within a few kilometres of Maya sites. Alexandra Witze

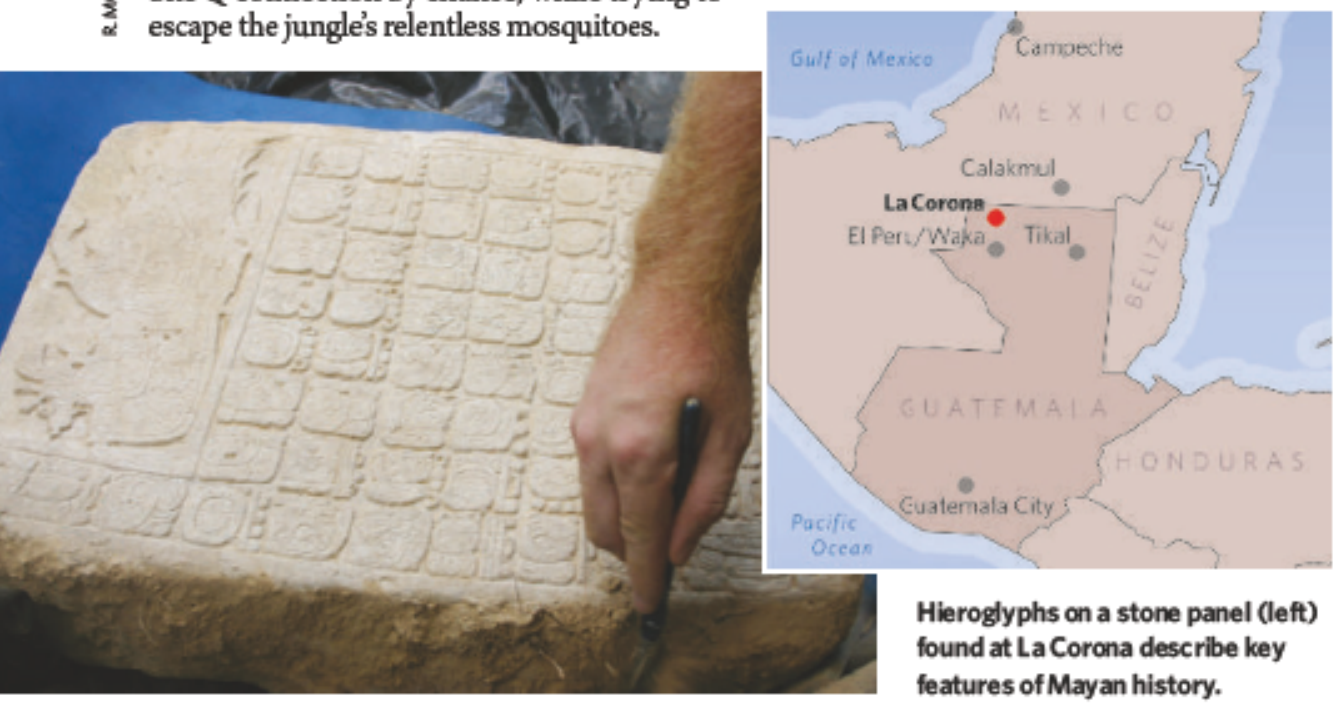

